\title{
'Sette on foote with gode Wyll': Towards a Reconstruction of Robin Hood and the Sheriff of Nottingham
}

\author{
Lythe and listin, gentilmen, \\ That be of frebore blode; \\ I shall you tel of a gode yeman, \\ His name was Robyn Hode. \\ A Gest of Robyn Hode ${ }^{1}$
}

In the greenwood of England, a game is afoot. Robin Hood, the noble bandit, has been identified as the audacious hero of Sherwood and Barnsdale for centuries, and his constant presence in ballads and drama since the fourteenth century attests to his popularity in and influence on the culture of the English nation. In a manuscript fragment of the late fifteenth century, ${ }^{2}$ the legend finds incarnation in a twenty-one-line drama (forty-two, if the caesurae are recognized instead as line-breaks), known by most scholars as Robin Hood and the Sheriff of Nottingham. The text contains no indication of scene-divisions or stage directions, and does not offer any notation to indicate the identity of the various speakers. Because the text offers so little in the way of definite answers, it invites interpretation. Despite their admirable efforts to treat the fragment, however, scholars have reached little consensus: critics, while advancing the probable accuracy of their own reconstructions, have yet to resolve some crucial difficulties that arise in the extant text. By reading the script Robin Hood and the Sheriff of Nottingham as a single and complete play-text, as I do in this re-examination, readers may reconcile its apparent inconsistencies.

Since the first extant record of Robin Hood in literature, in the fourteenth century Piers Plowman, tales and rhymes of the legendary outlaw have permeated Anglophone culture - a feat of public memory that, according to Stephen Knight, is surpassed only by stories of King Arthur. ${ }^{3}$ That the Robin Hood legend survives — and thrives — should not come as a shock; 
even in his earliest incarnations, he occupies a liminal space between social strata. R.B. Dobson and John Taylor describe the phenomenon by noting that 'Robin Hood possesses many of the knightly virtues and much of his behavior can be interpreted as that of a courtly hero transferred to a lower social plane ... [W] hat especially distinguishes him from all other outlaws was his "curtesye". ${ }^{4}$ Indeed, Robin's status as a yeoman between the fourteenth and sixteenth centuries makes him a prime figure to symbolize Englishness in the period, 5 just as his later incarnations adapt and shift to suit the demands of each new age. ${ }^{6}$ As a yeoman, he is of the rising middle class, and he is of 'frebore blode,'7 perhaps landed, and certainly largely independent - both of a feudal lord and sometimes of the law. The early Robin acts justly and honourably, but is hardly the altruistic dispossessed nobleman of the modern filmic imagination. He remains, ultimately, outside the law, preferring to enact his own brand of justice, and right the wrongs that seem most egregious to him, or which will most directly lead to his own profit. ${ }^{8}$ The early ballads resound with bloodshed and danger, and thus, it seems, are ideally suited for the stage.

Robin Hood's action-based legend holds special allure for both actors and audiences' ${ }^{9}$ and according to Knight and Thomas Ohlgren, 'it is not exaggerating to say that Robin Hood plays were the most popular form of dramatic entertainment in provincial England for most of the sixteenth century.' ${ }^{10}$ For Thomas Hahn, this phenomenon is only natural: 'Outlaw heroes are, in a categorical way, transgressors; yet, because their activities never take place in the "real" world, but always occur in the sphere of representation ... their transgressions invariably have about them an element of play'. ${ }^{11}$ This element of play exists in all of the ballads and dramas of Robin Hood, and the legend thus finds a comfortable place in the carnivalesque, which aims a critique at the existing social order, and attempts to break from the constraints of existing hierarchies. Scholars find this criticism of the status quo resounding through the lively and loud Robin Hood tradition; Peter Stallybrass suggests, '[Robin] inverts social hierarchy, preying upon the dominant classes; he degrades the sacred, humiliating the clergy.'12 Importantly, the popularity of the tradition lies in the careful navigation of inversion and play. Robin Hood does indeed adequately represent the topsy-turvydom of the carnival tradition, and that tradition is prevalent in much of folk drama, but as part of a practice of community games and dramas - like the May games, which Christine Richardson has called 'one of the strongest manifestations of the carnival or popular festive tradition', ${ }^{13}$ - no inversion would actually 
threaten hierarchical norms. Indeed, James Stokes has noted that 'there was apparently no doubt in anyone's mind that these were mimetic games, not insurrections. ${ }^{14}$ Community drama was entertainment, first and foremost. It acted, additionally, as a fundraising endeavour, and thus characters like Robin Hood (whose popularity with audiences, as some scholars have noted, brought in significant revenue) would have to remain familiar and congenial enough to encourage charity. ${ }^{15}$

The incipit to the play fragments of Robin Hood and the Potter and Robin Hood and the Monk place the texts firmly in the context of the May games, reading 'Here beginnethe the Playe of Robyn Hoode, verye proper to be played in Maye games. ${ }^{16}$ In her production notes for a Poculi Ludique Societas production of the two texts (presented as a coherent single play titled Robin Hood and the Friar), Mary Blackstone remarks that the drama would have had more of a visual than a textual appeal for its audiences, ${ }^{17}$ which makes it all the more appropriate for summer games, where action tended to predominate over plot. Though the plays were clearly staged during the games, the exact role of Robin Hood himself in the festival has been a subject of dispute. Richardson sees Robin as a clear 'ritual seasonal new King'18 whose presence can be taken mythologically and ritually. Dobson and Taylor disagree, finding no evidence to suggest that the proximity of the Robin Hood plays to the folk festival indicates that Robin Hood must be seen as some sort of 'mythological divinity'. ${ }^{19}$ Knight, while acknowledging that the Robin Hood plays had a part in welcoming the summer, cautions against connecting Robin to the mythological fertility rituals of May Day, offering instead a claim that Robin Hood's time is Whitsun, or the celebration of the Pentecost. ${ }^{20}$ David Wiles uses this connection to Whitsun to argue not for Robin's identification with a divine, mythological 'Summer Lord', but as a variant: a 'Whitsun King. ${ }^{21}$ He notes evidence of king games, like those of the May games, present also at Whitsun, and asserts that Robin, ultimately, represents both outlawry and inversion and the invocation of spring. ${ }^{22}$

Though the dramatic fragment Robin Hood and the Sheriff of Nottingham bears no incipit naming it as a performance at the May games, very likely it belongs to the same tradition. Scholars of the text tend to simply grant that connection in their reconstructions, and David Wiles even offers a maypole as a possible set piece. ${ }^{23}$ The context is undisputed; the source for the storyline, however, does not meet with such favourable unanimity. Most critics proceed from an assertion, made by F.J. Child in the late nineteenth century, that the fragment relates intimately to the ballad Robin Hood and Guy of 


\section{Alexis Butzner}

Gisborne. Dobson and Taylor say that although the fragment 'never mentions Guy of Gisborne's name [it] is clearly adapted from the ballad now known by that name'. ${ }^{24}$ George Parfitt, in his reconstruction, also assumes the connection. Wiles, on the other hand, finds the claim troubling. He believes that 'the second scene has no apparent connexion with the ballad', 25 and argues that reconstructions based on the assumption overlook the simplicity of the text at hand. Knight and Ohlgren, along with John Marshall, neither deny nor accept wholesale the connection between the ballad and the play fragment. Knight and Ohlgren acknowledge the distinct similarities between the two, but mark 'major differences' 26 as an indicator that they both come from another very distant common source. Marshall agrees, and indeed notes that the play fragment cannot be a direct descendent of the extant ballad of Guy, since 'the ballad survives only in a seventeenth century manuscript ${ }^{27}$ and the play dates to circa 1475 . Nonetheless, despite the late date of the extant ballad, and despite Wiles's rejection of the idea, a number of textual concordances support a close relation between the two. Probably the common source between the two is simply an older text of the same ballad of Robin and Guy; its survival in a seventeenth-century version does not preclude the possibility that it is a copy of an older text, or otherwise related in some way to the dramatic fragment.

An examination of the full text of Robin Hood and the Sheriff of Nottingham may help to demonstrate the similarities mentioned:

Syr sheryffe for thy sake

I wyll the gyffe golde and fee

Robyn hode ffayre and fre

with the shote y wyll

Have at the pryke.

late vs caste the stone

late vs caste the exaltre

syr knight ye haue a falle.

Owte on the I blowe myn horne.

lat vs fyght at ottraunce

Now I haue the maystre here

This knyghtys clothis woll I were welle mete felowe myn

Robyn hode and his menyet sette on foote wt gode wyll
Robyn hode wull y take.

This be heste $\mathrm{Pu}$ holde me.

vndre this lynde shote we.

Alle thy lustes to full fyll.

And y cleue the styke.

I grūnte well be seynt Iohn.

have a foote be fore the.

And I the Robyn qwyte shall

hit ware better be vn borne.

he that fleth god gyfe hym myschaunce. 10

off I smyte this sory swyre

And in my hode his hede woll bere.

what herst $\mathrm{Pu}$ of gode Robyn

with the sheryffe takyn be.

And the sheryffe wull we kyll 
Be holde wele ffrere tuke

3eld yow syrs to the sheryffe.

Now we be bownden alle in same

Come Pu forth Pu false outlawe.

Now allas what shall we doo

Opyn the yatis faste Anon howe he dothe his bowe pluke

Or elles shall yor bowes clyffe.

ffrere Tuke Pis is no game.

Pu shall be hangyde and y drawe.

we moste to the prysone goo

The setting for the fragment is established in line 3, with the phrase, 'under this lynde shote we'. In Robin Hood and Guy of Gisborne, the setting is identical: the action occurs 'amongst the leaves a lyne' (6). And the action, though Wiles asserts that the fragment has too much of it, lines up as well. Both have an archery competition, shown in the fragment in lines 3-5, and in Guy between lines 90-130. The exchange during the archery contest in the fragment of 'have at the pryke / and y cleue the styke' (5) also finds a parallel in Guy: 'Robin Hoode shott it better than hee, for he clove the pricke-wande' (125-6). Both the fragment and the ballad contain a duel, the end of which leads to the decapitation of one of the knights and the disguising of Robin in his clothes (Sheriff9-13). In the ballad, the scene is longer and more elaborate, and includes the macabre act of sticking the decapitated head onto the end of Robin's longbow (163-4), but follows a structure identical to that of the fragment. In both stories, the sheriff has apparently hired the knight to capture Robin, and the sheriff appears in both following a horn blast and the death of the knight (Sheriff 17).

The closeness of these plot points and the similarity of the language alone is convincing enough to argue for the possibility of a common source more contemporary with the play fragment; another compelling reason to believe in such a theory lies in the commonly accepted claim that the two play fragments mentioned earlier both have extant ballad relatives. Even Wiles, so adamant against assuming a connection between Robin Hood and the Sheriff of Nottingham and Robin Hood and Guy of Gisborne, recognizes that both Robin Hood and the Monk and Robin Hood and the Potter are based on ballads, and he also acknowledges that from those ballads 'a comparison can be made with two texts which date ... to the eighteenth century'. ${ }^{28}$ Since Wiles admits both contemporary literary relatives to the two plays, and a connection between those ballads and texts surviving into the eighteenth century, his denial of an analogous relationship between Sheriff and Guy seems unfounded. 
With regard to the text of the fragment and its possible reconstruction, critical consensus has been difficult to establish. The trouble begins immediately: despite an almost unanimous acceptance of the title Robin Hood and the Sheriff of Nottingham, (the exceptions being David Wiles, who simply refers to it as the 'dramatic fragment', and J.M. Manly, who calls it Robin Hood and the Knight) none of the previous reconstructions offer a location for the action, either omitting a setting entirely, or placing it noncommittally in an unnamed forest or greenwood.

The dramatis personae occupying that greenwood are the source of some obvious consistencies across all existing editions of the piece. They mention four characters by name: first, the 'sheryffe' and Robin are identified by the speaker in line 1 . The action seems then to proceed toward a challenge, in line 3, by that same speaker, who is then addressed as 'syr knight' in line 8 by the same character who comes to lop off 'this sory swyre' in line 11 . The fourth character mentioned is Friar Tuck, whose appearance comes at line 18. Perhaps because of these naming-instances, the initial exchange between the knight and the sheriff is fairly uniform across the published reconstructions. The exception is George Parfitt, who so wholly accepts the premise that the ballad and poem are impossible to disentangle that he casts the knight immediately as 'Guy'. ${ }^{29}$ The order of the speakers during the competitions remains likewise consistent across the various interpretations, although Wiles posits Robin as the perpetual challenger up to the wrestling match.

Dobson and Taylor, as well as Marshall, declare Robin the winner of every contest; Manly pictures Robin winning both the archery and the stonethrowing; Knight and Ohlgren give the archery contest to Robin, but leave the stones and caber-toss unsettled; Wiles offers no proposed winner for any of the three contests in his stage directions; and Parfitt, who adds no stage directions to his reconstruction, provides no opinion. Though he assigns a winner in each contest (Robin), Marshall concedes the possibility of improvisation in the context of the May games, saying that 'it is possible that the result was left unspecified to allow for genuine competition on the day'. ${ }^{30}$ This possibility is also supported by Clifford Davidson, who cites the static literary study of dramatic texts as eclipsing the inherently improvisational nature of performance. ${ }^{31}$

After the three contests, one of the competitors suggests that they 'have a foot before' them, which Marshall reads as suggesting the adoption of a wrestling stance; ${ }^{32}$ Knight and Ohlgren translate it as 'half a foot', ${ }^{33}$ but still agree that the contest that follows is a wrestling match. Only Parfitt, 
Manly, and Dobson and Taylor follow the interpretation that Robin puts forth this challenge. The arrangement of speakers, at this point in the text, becomes especially problematic. Of the six reconstructions, no more than two agree completely, and none agree with the order proposed below in this interpretation. Manly and Parfitt, following Robin's mocking 'syr knight, ye have a fall', have the knight both vow revenge and raise the horn to his lips; Robin then warns 'hit ware better be unborne' and suggests a fight to the death. Both scholars grant the knight the last word, with 'he that fleth, god gyfe him myschaunce'. Knight and Ohlgren agree with Wiles's version, which has Robin blowing the horn, the knight offering the warning, and Robin both proposing the duel and pre-emptively condemning cowardice. Marshall allows Robin only one piece of dialogue in this section, ascribing to him the claim and action of the horn-blowing. Taylor and Dobson almost entirely reverse that order, having the knight blow the horn, and giving the remainder to Robin. None of the critics offers explanations for their wildly different readings, and no direct evidence in the ballad of Guy implies any explanation (for those who admit to following the ballad).

Starting at line 13, all of the published reconstructions delineate the remainder of the text as 'Scene 2' (or, in Wiles's case, 'Play 2'). The overwhelming majority assign the lines about the sheriff's capture of Robin to the two outlaws; Knight and Ohlgren leave them unnamed and unspecified, and also take the words to be true (which would indicate a significant time lapse between the action of the two scenes). Wiles also takes the statement of Robin's captivity at face value. Parfitt, agreeing with Dobson and Taylor, asserts that the speakers are Will Scarlet and Little John, and makes no assumption that Robin has truly been captured; unfortunately, this contention derives from Will Scarlet's presence in the ballad of Guy, but Scarlet's role in the ballad is a completely silent one, and in the ballad Little John has been imprisoned before Robin even meets Guy. Both Marshall and Wiles believe that Friar Tuck and Little John are the speakers, because that assignment ties in well with the later conversation, ending in 'Be holde well Ffrere Tuke, howe he doth his bowe plucke'.

Just as with the rest of the text, the end of the play has come under considerable scrutiny, and has found little consensus. Manly says simply, 'The part of the play where Robyn follows his men and finally releases them is missing. ${ }^{34}$ For the critics who have Robin jailed at the conclusion, a daring attack on the sheriff followed by an escape seems the most probable ending, although if the sheriff has enough men to overcome the outlaws in the field, 
why would his men suddenly suffer defeat at the hands of a single added unarmed man? Marshall, however, proposes a silent finale, utilizing the disguised Robin and allowing for the text to not be fragmentary after all. In Marshall's interpretation, Little John and Friar Tuck have been locked away. Robin arrives, still dressed as the knight, and as such gains clearance from the guards or the sheriff to enter the prison. When Robin frees his men, a brief fracas ensues, with the outlaw and his men gaining the ultimate prize of victory: their freedom.

Although the inconsistency of interpretation discussed above suggests that Robin Hood and the Sheriff of Nottingham poses too difficult a puzzle to solve, a holistic view of the previous scholarly work and the text itself indicates that a reliable reconstruction of the fragment is indeed possible. Though most critics view the fragment as being two distinct scenes, the following is assembled into a single scene for ease of performance; the stage, or staging area, requires only a backdrop of trees to represent Sherwood Forest, a bull's-eye for the archery competition, and a structure to act as both a prison and the residence of the sheriff of Nottingham. Hand properties would be limited to the weapons, horn, and objects of competition (stones and a caber) explicitly mentioned in the text, and costuming would be simple: it is unlikely that the knight would be wearing armour in a non-ceremonial ground-combat situation. The actors themselves would likely have been, at the time of its original production, local amateurs rather than professionals, since audience demand for rough-and-tumble action would be more important than the play-text's minimal demand on memory. ${ }^{35}$ Robin and his men would be dressed in the traditional Lincoln green, for, as Claire Sponsler notes, 'while dressed in green, Robin Hood's identity is clearly displayed on his body ... [and] so clearly identifies him as a denizen of the greenwood'. ${ }^{36}$

To simplify reading of the reconstruction, I have rendered sigla and obsolete letters in their full form, and have modernized orthographically similar letters (u, v, y, i), added punctuation, and glossed obscure words or spellings. In addition, I renumbered the lines based upon the caesurae placement in the manuscript.

\section{Reconstruction of Robin Hood and the Sheriff of Nottingham}

$\begin{array}{lll}\text { Dramatis Personae: } & \text { Robin Hood } & \text { Sheriff of Nottingham } \\ & \text { Friar Tuck } & \text { Knight } \\ & \text { Little John } & \text { Sheriff's men }\end{array}$


[At the entrance to the prison]

KNIGHT Syr sheryffe, for thy sake

Robyn hode wull I take.

SHERIFF I wyll the gyffe golde and fee.

This be heste thou holde me.

[Sheriff exits into prison; the Knight travels to the edges of Sherwood Forest, where he encounters Robin Hood.]

KNIGHT Robyn hode, ffayre and fre,

undre this lynde shote we.

ROBIN With the shote I wyll,

Alle thy lustes to full fyll.

[The Knight shoots and hits the bull's-eye.]

KNIGHT Have at the pryke.

[Robin shoots, splits the wand down the centre]

ROBIN And I cleve the styke.

KNIGHT Late us caste the stone.

ROBIN I graunte well, be Seynt John.

\section{[They throw stones.]}

KNIGHT Late us caste the exaltre.

[They heave the axle.]

ROBIN Have a foote be fore the.

[They wrestle: Robin throws the Knight.]

Syr knight, ye have a falle.

KNIGHT And I the Robyn qwyte shall.

[The Knight rises and draws his sword.]

4 Be heste : promise

6 Lynde : linden tree shote : shoot

8 lustes : desires, wishes

9 pryke : bull's eye, target.

9.1 According to Knight and Ohlgren, 'to split the wands was the greatest skill' (266).

12 graunte : concede, allow.

13 exaltre : wagon axle

16 qwyte : repay 
ROBIN Owte on the! I blowe myn horne.

Hit ware better be un borne.

[Robin blows his horn.]

KNIGHT Lat us fyght at ottraunce.

he that fleth, god gyfe hym myschaunce.

[They fight; after a long battle, Robin vanquishes the Knight.]

ROBIN Now I have the maystre here;

off I smyte this sory swyre.

[Robin decapitates the Knight.]

This knyghtys clothis woll I were

And in my hode his hede woll bere.

[Robin disguises himself in the Knight's clothes; the Sheriff and his men arrive, having mistaken the horn blast for a sign from the Knight that Robin has been captured, and Robin is mistaken for the Knight. Meanwhile, Little John and Friar Tuck, also responding to the horn blast, approach; they also fail to recognize the disguised Robin, and, seeing the Sheriff, conceal themselves.]

SHERIFF Welle mete, felowe myn.

what herst thou of gode Robyn?

ROBIN Robyn hode and his menye

With the sheryffe takyn be.

[Robin exits; Little John and Friar Tuck, still concealed, begin to speak.]

LitTLE JOHN Sette on foote with gode wyll,

And the sheryffe wull we kyll.

FRIAR TUCK Be holde wele ffrere Tuke,

howe he dothe his bowe pluke

[The Sheriff sees the hidden outlaws.]

SHERIFF Yield yow, syrs, to the sheryffe,

or elles shall your bowes clyffe.

[Little John steps forward into the waiting cohort of lawmen; Friar Tuck holds back, unafraid.]

19 at ottraunce : to the bitter end, with the utmost force.

20 fleth : flees myschaunce : misfortune

21 maystre : mastery, upper hand

22 swyre : neck

34 clyffe : cleave, break. 
LiTTLE JOHN Now we be bownden alle in same,

ffrere Tuke, this is no game.

SHERIFF Come thou forth, thou false outlawe.

Thou shall be hangyde and y drawe.

[Friar Tuck is apprehended by the Sheriff's men and the prisoners are escorted to the gates of the prison.]

FRIAR TUCK Nowe, allas! What shall we doo?

LITTLE JOHN We moste to the prysone goo.

SHERIFF Open the yatis faste Anon

And late theis thevys ynne gon.

The action described in this reconstruction follows, to some extent, the plot of Robin Hood and Guy of Gisborne. I chose the initial setting of Sherwood Forest and Nottingham both because there is no well known sheriff figure associated with Barnsdale, the other location of the ballads and plays, and because of instances in Guy where Little John departs from Robin to go to Barnsdale (45) and where the sheriff of Nottingham receives direct mention (185).

This reconstruction holds true for the order and structure of the initial exchange between the knight and the sheriff proffered by other reconstructions. As to the speaker order of the challenges starting at line 5, since critical consensus leans in the direction of the knight being the challenger, and since Wiles offers no compelling reasons (indeed, he mentions none at all) for his change, probably the initial challenge and deferral, wherein the knight says 'under this lynde shote we' and Robin courteously obliges, set the stage for a series of exchanges led by the knight.

Once the characters start their competition, the interpretation presented here follows the Knight and Ohlgren reconstruction, and allows for some improvisation, though not in the archery contest. Both the apparent order of the speakers and Robin's association with archery - which is as much a means of manifesting his character identity as his garb of Lincoln green create the overwhelming impression that the knight loses that first contest.

38 hangyde and y drawe : hanged and disemboweled; the " $y$ " here is not an "I," but rather a past-participle marker.

41 yatis: gates

42 late: let thevys: thieves 
The wrestling scenario offered here suggests that Robin puts forth the challenge, appropriate given that wrestling is not particularly aligned with the (supposedly) chivalrous. Despite the fact that Knight and Ohlgren's edition puts the challenge in the mouth of the knight, they acknowledge in the context of the Gest of Robyn Hode that 'wrestling was not, by the fourteenth century, considered an aristocratic sport. ${ }^{37}$ Certainly Chaucer did not think so. In his Tale of Sir Thopas, a sharp burlesque on the courtly genre of romance, the 'protagonist' is a diminutive, effeminate knight with an empty sword sheath, an imaginary lover, and a talent for wrestling. Throughout the course of the tale, poor Thopas faces endless lampooning, and comes out the other side of his saga barely recognizable as a knight at all. Thus, evidence suggests that, mercenary though he may be, the knight of the play-text still represents knighthood, and it seems much more likely that Robin would propose the lesser sport of wrestling than he.

Given the wide array of interpretations regarding the horn blast, a reexamination of Guy is crucial, since, as mentioned above, it did not align with the previous reconstructions, but does in fact offer a clue upon which we might base an interpretation of the action. This clue comes in the lines 'Robin sett Guyes horne to his mouth, a lowd blast in it he did blow' (1834). In the ballad, this action occurs after Guy has been killed; nonetheless, it provides a starting-point for the interpretation provided here, which has Robin blowing the horn and responding to the threat of 'qwyting' by saying 'it were better be unborne'. The remaining two lines I ascribed to the knight both for balance in the verbal interchange and because both 'ottraunce' and 'myschaunce', with their-aunce suffixes, are French-derived and thus more appropriate to the knight than to a simple yeoman-bandit. ${ }^{38}$

The horn-blowing of these few lines becomes crucial for the reconstruction proposed. Though Wiles asserts that there is 'nothing heroic about Robin' here in his calling for assistance, he bases that claim on the assumption that the knight's threat to 'qwyte' Robin denotes merely another stage in the wrestling match. Marshall, however, recognizes instead the possibility that the knight, having just been thrown himself, has lost control and entered a fit of rage, the result of which naturally escalates the danger involved in the competition. ${ }^{39}$ What neither critic remembers, however, is that this competition could never have been called a friendly game; though Robin may not have known it when he assented to the archery contest, the knight's appearance came as a direct response to the sheriff's bidding. The knight never intended Robin to walk away from their encounter — his goal was to shackle 
the bandit and drag him off to prison, or simply to kill him. The knight's intentions assume little relevance in the actual events of the play, however. Robin slays him, chops off his head, and dresses in his clothes.

This interpretation follows Marshall's and Wile's determination that the two speakers at lines 29-32 are Friar Tuck and Little John. For those scholars who assign the previous exchange to others, a central marker of Friar Tuck's character, as well as a considerable amount of comedy, gets lost. Friar Tuck is often figured as a boastful, good-humoured man: in the dramatic rendition of 'Robin Hood and the Monk,' he says of himself, 'Am not I a jolly fryer? For I can shote both farre and nere, and handle the sword and buckler, and this quarter staffe also' (25-8). Marshall and Wiles appreciate the buffoonery of Tuck here, a buffoonery that surely would not have been lost on a theatrical audience.

The reconstruction proposed here discards the scene division entirely in favour of an interpretation that makes full use of the horn-blast so contentiously passed from mouth to mouth in the other reconstructions. What seems most likely, especially in light of the short length of the text, is that the play intends a single unified performance, with no temporal or logical jump required to understand the action clearly. In Robin Hood and Guy of Gisborne, the horn blast acts as an unintentional signal to the sheriff of Nottingham. He arrives, mistakes Robin for the knight, and the action proceeds from there. Plausibly this same occurrence has happened in the play-text, and Robin's own men also hear the blast. Then, the exchange regarding Robin's status becomes a deceit on the part of Robin to appease the sheriff, and the outlaw walks away unharmed. In addition, this reading explains the subsequent behaviour of Robin's men, who are also hoodwinked in the bargain that saves Robin's life, in a series of farces (they are forced to conceal themselves for fear of the sheriff, they are tricked into believing the 'knight's' duplicity, and they are found cowering in the trees and forced into the open), which allows the drama to maintain the playfulness of the Robin Hood tradition as Robin and his men work to exact their humiliating revenge on the authorities.

When Friar Tuck holds back even after the sheriff's first threat and Little John's surrender, he continues the humour of his self-conceit, probably mocking the sheriff's men as John says, 'this is no game', and then becoming hilariously deflated when the swaggering Friar bewails his plight on the way to the prison. That Tuck has stood his ground here is absolutely apparent. Most reconstructions seem to disregard the fact that the sheriff uses a 
singular noun when he calls out again for surrender: 'come thou forth, thou false outlawe' certainly indicates one person. Knight and Ohlgren have the sheriff say this outside the prison to a Robin Hood confined inside, and Wiles agrees, but no evidence supports this conjecture. Despite these considerations of the text and its context, not a single interpretation of the text has acknowledged the possibility in the play that the piece is one scene, ${ }^{40}$ and that Robin interacts with the sheriff duplicitously. ${ }^{41}$ Instead, the critics insert unnecessary breaks of time and space, shifting the action to some unstipulated time after the disguising of Robin, away from the place of the knight's death, and tendering a hero who is not only absent, but possibly imprisoned.

These changes feel unnecessary, given the evidence the text provides; declaring the text a certain fragment seems similarly unnecessary. Marshall's interpretation of a silent ending, discussed above, eliminates the need for additional play-text while still enacting a complete and highly entertaining ending. In this ending, more appropriately termed 'unscripted' than silent, full use can be made of the physicality that drives the remainder of the text, by having Robin approach the prison into which the sheriff has just thrown his fellows. Still in disguise, the sheriff and Robin would likely cross paths as the hero heads on his way to thwart the authorities one last time. Since the audience would have the benefit of knowing Robin's true identity, he could easily play up his interaction with the sheriff as a means of adding more depth and comic business, and of iterating the complicity between Robin and the audience in one extended inside joke at the lawman's expense. The release of the sidekicks in the presence of the guards (and potentially the sheriff himself, if he has not yet made it out of sight) would necessitate a final chase and fight scene, a literal 'visual assault' to reinforce the nature of the remainder of the play. Robin and his men would, of course, be triumphant. Because music was a common element of folk celebrations, and of Robin Hood plays in particular, ${ }^{42}$ this final scene could either enact a dance following the completion of the fight, or the two could intertwine, utilizing the maximum amount of space for the movement of actors as they dance and fight. Given the ease with which the 'lack' of an ending can be resolved, it thus seems plausible to assume that the short 'fragment' can instead simply be read as the skeletal framework for a single-act performance, a mélange of improvisation, comedy, action, and a familiar Robin Hood tale.

Clifford Davidson essentially precludes the possibility of determining a static interpretation of a text such as Robin Hood and the Sheriff of Nottingham: 'the idea of fixed authorship and definitive texts must be put aside for a 
theater that was more fluid and more open to changes as anonymous scripts were revised'. ${ }^{43}$ Nonetheless, the reconstruction posited here would seem to offer one version of the text that allows for the interplay of text and improvisation without betraying the text itself as it stands today. It could have been performed at the May games, or in other community settings; it might have, like so many other Robin Hood plays, brought in much needed funds for parishes or towns. More importantly, however, audiences of this particular rendering of the drama would have found something entertaining and full: a carnivalesque execution of the action- and comedy-packed folk drama of the May games. They would have the backdrop of the greenwood and of a familiar ballad tradition. They would have Robin Hood.

\section{Notes}

An earlier version of this article was presented at the 7th Biennial International Association of Robin Hood Scholars Conference in 2009. I am grateful to Stephen Knight, Thomas Hahn, and Dean A. Hoffman for their helpful comments at that conference. Special thanks goes to Jonathan Walker at Portland State University for his invaluable insight and guidance across much of the duration of this project.

1 All references to early Robin Hood texts cited here come from Stephen Knight and Thomas Ohlgren (eds), Robin Hood and Other Outlaw Tales (Kalamazoo, 2000), hereinafter cited as Outlaw Tales.

2 The fragment has been linked by several scholars to the prominent Paston household, whose collection of family letters and documents have been a source of much scholarly interest. Indeed, David Wiles, The Early Plays of Robin Hood (Cambridge, 1981), surmises of the manuscript that it was likely 'circulated among the servants of one of the Paston households. The copy that survived belonged to a servant who had no further use for it after Whitsun 1475' (36).

3 Stephen Knight, 'Remembering Robin Hood: Five Centuries of Outlaw Ideology', European Journal of English Studies 10.2 (2006), 149.

4 R.B. Dobson and J. Taylor, Rymes of Robyn Hood (Pittsburgh, 1976), 32.

5 Douglas Gray, 'Everybody's Robin Hood', in Robin Hood: Medieval and Post Medieval, ed. Helen Phillips (Cornwall, 2005), 40.

6 John Marshall, 'Gathering in the Name of the Outlaw: Reed and Robin Hood', Audrey Douglas and Sally-Beth MacLean (eds), REED in Review: Essays in Celebration of the First Twenty-Five Years (Toronto, 2006), 65.

7 Knight and Ohlgren, Outlaw Tales, 90. 
8 For more on Robin's elastic identity, and his elastic ethical sense, see Marshall, 'Name of the Outlaw' and Stephen Knight's Robin Hood: A Mythic Biography (Ithaca, 2003).

9 Knight and Ohlgren, Outlaw Tales, 7.

10 Ibid, 269.

11 Thomas Hahn, 'Playing With Transgression: Robin Hood and Popular Culture', Thomas Hahn (ed.), Robin Hood in Popular Culture (Cambridge, 2000), 1.

12 Peter Stallybrass, "Drunk with the cup of liberty”: Robin Hood, the Carnivalesque, and the Rhetoric of Violence in Early Modern England', Stephen Knight (ed.), Robin Hood: An Anthology of Scholarship and Criticism (Rochester, 1999), 299.

13 Richardson, 'The Figure of Robin Hood', 18.

14 James Stokes, 'Landscape, Movement, and Civic Mimesis in the West of England', Early Theatre 6.1 (2003), 40.

15 A great deal of work has been done establishing the connections between folk drama such as happened during summer games and parish and regional fundraising. For more information, see Marshall 'Name of the Outlaw', and Stokes, 'Civic Mimesis'.

16 Knight and Ohlgren, Outlaw Tales, 286.

17 Mary A. Blackstone, Robin Hood and the Friar, pls Performance Text: No 3 (Toronto, 1981), 1.

18 Richardson, 'The Figure of Robin Hood', 23.

19 Dobson and Taylor, Rymes of Robyn Hood, 38.

20 Stephen Knight, Robin Hood: A Mythic Biography (Ithaca, 2003), 12.

21 Wiles, Early Plays, 8.

22 Ibid, 19.

23 Ibid, 38.

24 Dobson and Taylor, Rymes of Robyn Hood, 37.

25 Wiles, Early Plays, 33.

26 Knight and Ohlgren, Outlaw Tales, 271.

27 John Marshall, 'Playing the Game: Reconstructing Robin Hood and the Sheriff of Nottingham', Hahn, Robin Hood in Popular Culture, 161.

28 Wiles, Early Plays, 40.

29 George Parfitt, 'Two Fragments', 5.

30 Marshall, 'Playing the Game', 167.

31 Clifford Davidson, 'Improvisation in Medieval Drama', Timothy J. McGee (ed.), Improvisation in the Arts of the Middle Ages and Renaissance (Kalamazoo, 2003), 193.

32 Marshall, 'Playing the Game', 167.

33 Knight and Ohlgren, Outlaw Tales, 276.

34 J.M. Manly, Specimens of the Pre-Shakespearean Drama, 2 vols (Boston, 1897): 1.281. 
35 Blackstone, Robin Hood and the Friar, 8.

36 Claire Sponsler, Drama and Resistance: Bodies, Goods, and Theatricality in Late Medieval England (Minneapolis, 1997), 31.

37 Knight and Ohlgren, Outlaw Tales, 157.

38 For more on the chivalric consequences of the knight's language here, see Marshall, 'Playing the Game': 'It is ... a technically appropriate term for the knight to register the escalation to armed combat' (170).

39 Ibid, 169.

40 Manly's edition is somewhat ambiguous on this point, as the reconstruction offers the following stage direction at the moment of Robin's apparent disguising: 'He disguises himself. Meantime the Sheriff has attacked Robyn Hode's men and a fierce battle is in progress. Robyn meets a man coming from the scene of the battle' (1.280). This could suggest a fully contiguous procession of the action (thereby indicating a single overall 'scene'), or could indicate a break-away to another scene that Robin subsequently enters.

41 Although Manly does have Robin dupe someone else (an unidentified 'man') while disguised as the knight, he does not see Robin as magically ending up in the prison.

42 Blackstone, Robin Hood and the Friar, 10.

43 Davidson, 'Improvisation', 193. 